\title{
Accomplishments in Learning Self-Regulation in Personal Environments
}

\author{
Eduardo Chaves-Barboza, Juan M. Trujillo-Torres, Juan A. López-Núñez* \\ Faculty of Education Sciences, Campus Cartuja s/n - CP 18071, University of Granada, Granada, Spain \\ Email: eduardochb@ugr.es, jttorres@ugr.es,
}

Received 4 May 2015; accepted 23 June 2015; published 26 June 2015

Copyright (C) 2015 by authors and Scientific Research Publishing Inc.

This work is licensed under the Creative Commons Attribution International License (CC BY). http://creativecommons.org/licenses/by/4.0/

(c) (i) 0pen Access

\section{Abstract}

This article aims to analyze the accomplishments in learning self-regulation from a student population in personal learning environments. A Likert scale-like questionnaire is applied to a random cluster sample of students from the Pedagogy, Social Education and Psychopedagogy degrees from the University of Granada, Spain. Descriptive or inferential analyses are carried out along the research in order to characterize the population. Additionally, Kendall's correlation coefficients are calculated and interpreted to define the relations among students' accomplishments. Finally, Kruskal-Wallis $H$ tests are performed to ascertain through analysis of variance if the variable degree influences such accomplishments. The results show that the students from these three degrees set goals, perform tasks in an organized manner, accomplish extra work on time, meet the deadlines to hand in the class-work, and reflect on their learning. Pedagogy presents the highest relation between achieving an appropriate period of time to perform the tasks and carrying out their extra work on time. Social Education shows a smaller number of students and less intensity when meeting the deadlines to hand in the classwork. The students from Psychopedagogy have the highest accomplishments in reading the whole material suggested by the teacher. The research concludes that, although there are some variations among these three degrees, they are homogeneous in the majority of the variables studied here. The students succeeded in learning selfregulation; however, it is necessary to reinforce the time planning, the reading of the material suggested by the teacher, enhancement of knowledge, and complementary research. One student subgroup is distinguished for its accomplishments in task organization and performance, while other groups excel for deepening their understanding of the units and metacognition.

\section{Keywords}

Self-Regulated Learning, Personal Learning Environment, Learning Achievements, Higher Education

\footnotetext{
"Corresponding author.
} 


\section{Introduction}

\subsection{Self-Regulated Learning}

From the social cognitive perspective, learning represents a process through which the subject turns their mental abilities and epistemological beliefs into specific abilities and knowledge. In this theoretical model, the learner is perceived within a changing environment which leads them to make constant metacognitive efforts of assessment and feedback in order to adjust behavior and strategies. Thus, learning is considered as an interaction among intrapersonal, behavioral and environmental elements.

On the other hand, self-regulated learning is, for self-determined goals, a motivational and cognitive process of control, through which a person searches their environment adaptation (Carver \& Scheier, 1998). In general, behavioral self-regulation means that the subject sets and assesses goals, responds emotionally to the progress and manages sources aiming at the achievement of objectives or, alternatively, reacts to the lack of progress and abandons their objectives (Forgas, Baumeister, \& Tice, 2009).

From the social cognition perspective, self-regulated learning is regarded as an interaction between personal and environmental elements. The subject acquires knowledge and develops skills through the activation and maintenance of a cognitive process, which is behavioral and affective within a specific environment. This approach suggests that the subject is conditioned by external factors-social, political and economic, and internal factors - biological, emotional and cognitive. It also states that they have sufficient metacognitive skills to set, assess and modify their own goals, behavior, and learning strategies (Hadwin et al., 2010; Schunk, 2004; Schunk \& Zimmerman, 1994; Zimmerman, 1990, 2000, 2008; Winne, 2015).

From this perspective, self-regulated learning is a cyclical process divided into three stages: forethought, performance, and self-reflection (Jin \& Low, 2009; Pajares, 2002, 2007; Schunk \& Zimmerman, 2003; Zimmerman, 2015; Usher \& Pajares, 2008; Zimmerman \& Cleary, 2006, 2009; Zimmerman \& Schunk, 1989).

In the forethought stage, the subject sets their learning goals and plans all the strategies corresponding to such goals. In order to carry out this task, they must trust their own previous knowledge and capacities. Then, in the performance stage, the subject implements the strategies planed in the previous stage. Additionally, they perform control tasks throughout the accomplishments achieved in self-regulation and learning process, about selfmotivation, self-efficacy and self-expectations. Finally, in the self-reflection stage, the subject uses all the information obtained and experiences from the previous stage in order to restart the self-regulated learning cycle.

Along these three stages, the subject displays their initiative, tenacity and adaptability to avoid procrastination and achieve efficiency. It is crucial that the subject realizes their own efficacy (auto-efficacy) to achieve learning success as it will boost their motivation to continue the self-regulated learning cycle. On the opposite, the cycle will be stopped if there is no motivation (Schunk, 2004; Zimmerman \& Cleary, 2006; Usher \& Pajares, 2008; Zimmerman, 2008; Jin \& Low, 2009; Vanthournout et al., 2015; Nelson et al., 2015). Perception of their autoefficacy requires the subject's metacognitive awareness of the learning tasks, own behavior, cognitive achievement, and chosen and used strategies (Schunk \& Zimmerman, 2003).

While self-regulated learning highlights the subject's management capacity, the whole process is performed within a social and virtual environment. This means that actions like their own behavior regulation, cognitive achievements monitoring, and strategies adaptation are carried out under the influence and participation of other learners, teachers and experts and an entire digitally linked social network (Haslaman \& Askar, 2015). Social influence over individual self-regulatory process is multidimensional and complex, where not only do the subjects show their own personal initiatives, but they also proactively pursue feedback and support from their partners, teachers, and learning environment (Rezaee \& Mosalanejad, 2015).

In the theoretical framework of self-regulated learning, particular emphasis is given to subject's personal circumstances and environmental and technological factors (Chaves, 2014; Broadbent \& Poon, 2015). These are key elements of another construct: PLE (Personal Learning Environment).

\subsection{Personal Learning Environment}

LMS (Learning Management Systems) are an attempt by universities to control learning in the presence of the Internet by using the traditional teacher/student role. Their implementation in higher education dates back to the $90 \mathrm{~s}$, when they were seen as an easy and flexible way of delivering teaching materials, managing activities and providing support to the students. Furthermore, LMS were thought to solve different challenges faced by higher 
education, such as the increase of expenses, budgets reduction, the need to be more competitive and the increase of students' heterogeneity. And then, as a consequence of the criticism of LMS and their traditional teaching approach, PLE came to life with great enthusiasm. This idea has spurred several publications in teaching technology magazines and conferences (Attwell, 2007b; Drexler, 2010).

PLE and related educational ideas are useful to study how the way people learn may be affected by the access to easy-to-use, ubiquitous and sophisticated technologies, which are increasingly abundant, integrated into daily life, adapted to individuals and adaptable by them.

Firstly, PLE may refer to a technological tool kit chosen, integrated and used by an individual in order to access new knowledge sources (Chatti et al., 2010). Therefore, it represents a pragmatic solution created by a person given their intrinsic learning capacity and day-to-day contact with technological tools. This is what Gillet and colleagues mean when they state that "Personal Learning Environments (PLE) are not monolithic systems. They can be simply a set of devices, tools, applications, and physical or virtual spaces associated by learners at a specific time, for a specific purpose, and in a given context. A student's desk covered by books and notes, combined with a computer holding a collection of slides and documents with the associated applications for reading and editing, integrating a browser to access the Web or just the institutional LMS, is already a PLE". (Gillet, Law, \& Chatterjee, 2010: p. 898). It is noted here that the LMS of the institution can be a constituent tool of the university student's PLE.

On the other hand, other authors present a more self-oriented vision on the tools composing PLE, in which technological tools are expanded or substituted for mainly intellectual capacities or actions of the subject. One such example is Ricoy \& Couto (2010: p. 2), who state that "each user can be autonomous, manage their time, the consultations carried out and dedication to learning via the Internet. This selection and the dynamics of personal and intellectual development is known as Personal Learning Environment (PLE)". Meanwhile, Attwell's vision is more integrative, as it indicates that a PLE is made up of all the different tools that the person used in everyday life to learning (Attwell, 2007a); and this can include not only physical and virtual tools, but also intellectual.

As we can observe in these PLE conceptualizations, learning processes within this environment require an active, convening and reflective role. Moreover, it implies performing self-regulated cognitive and metacognitive tasks by using ubiquitous resources of their PLE (Attwell, 2007a, 2007b; Chatti et al., 2010; Drexler, 2010; Johnson \& Sherlock, 2014; Väljataga \& Laanpere, 2010; Wilson, 2008; Wilson et al., 2007; Rahimi \& Jan Van den Berg, 2015; Chaves et al., 2015). Thus, it is pertinent to study how the subject achieves their self-regulated learning in their personal environment. This means goal-setting, choosing and managing their own contents, establishing communication with other students and teachers during their managements and finally, achieving their learning goals.

\subsection{Research Objectives}

This article's main objective is to analyze the accomplishments in self-regulated learning achieved by a group of students in their personal learning environment. To achieve this purpose, three specific objectives were proposed. The first one is to identify the accomplishments the students achieved in the self-regulated learning within their PLE. The second one is to comparatively study the accomplishment among the three different degrees. Finally, the third one suggests describing the meaningful relations between the achievements identified.

\subsection{Relevance of the Research}

The results of the research are important since they can help students better know their self-regulated learning processes in their environments (Zimmerman \& Cleary, 2006; Pajares, 2007; Usher \& Pajares, 2008; Zimmerman, 2008; Jin \& Low, 2009; Bandura, 1997). Self-regulated learning theory states that the subject's perception of their auto-efficacy to be successful in the learning process is really important as it guides or motivates the student to continue with self-regulated learning cycle. Empiric researches of this kind may help students develop a metacognitive awareness of their learning activities, their own behavior, and cognitive accomplishments. This way, they can gain more control over their learning self-regulation (Schunk \& Zimmerman, 2003).

In addition, teaching issues shown along this research are of potential interest for professionals in charge of University grade programs and generally for teachers, researchers, educational administrators and any teacher training managers. Self-regulated learning and PLE theorists and researchers give special importance to re- 
searching, assessing and showing every process carried out in PLE and in learning self-regulation. This makes sense as it is thought that teachers, training programs managers, partners, educational communities, social networks, and collective intelligence of the Internet support conclusively the process of behavior self-regulation and the conscious, reflective and self-regulated use of tools for achieving learning (Zimmerman, 2008; Ebner \& Taraghi, 2010; Godwin-Jones, 2009; Dabbagh \& Kitsantas, 2012; Johnson \& Liber, 2008; Liber \& Johnson, 2008; Archee, 2012).

\section{Research Methodology}

\subsection{Population and Sample}

This article shows the results obtained from a questionnaire applied to a random cluster sample in May and June, 2013. The research population is composed of the active students of the Pedagogy and Social Education fouryear degrees and of the Psychopedagogy five-year degree, qualifications belonging to the Faculty of Educational Sciences in the University of Granada (Spain). This population is composed of 1062 subjects, of which 814 are women and 248 are men. It is divided into 16 students groups: two groups in each level of each four-year degree and four groups in the five-year degree.

In order to sample this population, a cluster framework was established within the student groups. Then, seven groups with 299 people were randomly chosen. This sample allows the calculation of a $95 \%$ confidence interval $(95 \% \mathrm{CI})$. It is clarified that all the subjects were properly informed about the purpose of the research and they were guaranteed their privacy protection.

\subsection{The Questionnaire and Its Variables}

The questionnaire opens with nine general questions regarding sex, age, degree, number of hours devoted weekly to different activities and personal access to devices as smartphones or laptops. The main section of the questionnaire is composed of twelve items referring to accomplishments in learning self-regulation in PLE. These items are a four-level Likert scale (strongly disagree, disagree, agree, strongly agree).

While dichotomous and ordinal variables correspond to the nine general questions, the main items have twelve ordinal variables with four levels. The latter are called main variables as their analysis is indispensable for the goals achievement.

\subsection{Variables, Tests and Hypothesis}

The nine general variables were used to increase the population's characterization from the sample. With this purpose, a descriptive and inferential statistic was performed. When dealing with ordinal variables, the standard error of the mean (SEM) was also calculated, always at a 95\% confidence level (Aron, Coups, \& Aron, 2013).

Aiming to achieve the first research objective, the descriptive and inferential statistic was used with the twelve main variables of the questionnaire. Pursuing the second objective, Kruskal-Wallis H tests (Kruskal \& Wallis, 1952; Howell, 2014) were carried out with independent samples in order to determine if the variable degree influences any of the accomplishments achieved in this process. This means that for every pair degree-accomplishment, the equality in the variable accomplishment for the three different levels of the factor degree is a null hypothesis, and non-equality would be an alternative hypothesis. These tests were calculated and interpreted at a $95 \%$ confidence level with bilateral significance (two tailed tests).

In order to reach the third objective, Kendall's correlation coefficients (Kendall \& Stuart, 1979; Leech, Barrett, \& Morgan, 2011) were calculated and interpreted at a 95\% confidence level with bilateral significance. Linear correlation hypothesis were propounded for every pair of achievements. Each null hypothesis suggests that the correlation index among every pair of achievements is zero, while each alternative hypothesis entails every index is different from zero. The result is a correlation matrix. In the present article, only statistically significant correlations were included.

\subsection{Validity and Reliability of the Research}

The questionnaire was validated by ten experts on the issues it presents. The information offered by such experts was analyzed both quantitatively, using Osterlind index of congruence (Osterlind, 1989), and qualitatively, through 
codification and categorization processes, which allowed experts to incorporate suggestions in the questionnaire. Every single item in the questionnaire has an Osterlind index of congruence higher than .5, which proves the validity of this tool.

The questionnaire has used a pilot application which allows the analysis of the reliability of the tool through Cronbach alpha coefficient (Cronbach, 1951). The value of the alpha instrument is .927, which shows an excellent reliability.

\section{Tests Results}

\subsection{Population Characteristics}

In the research sample, $83.28 \%$ of the participants were woman and $16.72 \%$ are men. Such sex distribution was presented with a checked sampling error of $6.6 \%$. The median age of the population is $24.44 \pm 0.55$ (SEM $=.27$ ) years old. The median age for Pedagogy students is $23.37 \pm 0.78$ (SEM $=.39$ ), while students from Social Education have a median age of $25.03 \pm 1.42(\mathrm{SEM}=.71)$ and from Pysichopedagogy $25.24 \pm 0.49(\mathrm{SEM}=.24)$.

The average of weekly hours devoted to the use of their PLE tools is $17.01 \pm 1.74$ (SEM $=.88)$; using LMS is dedicated $6.52 \pm 0.78(\mathrm{SEM}=.39)$, and surfing the web takes $16.21 \pm 1.32$ hours (SEM = .67).

Of all the students, $93.31 \% \pm 2.83 \%$ have a laptop for personal use, $12.37 \% \pm 3.73 \%$ have a tablet and $38.79 \%$ $\pm 5.50 \%$ own a desktop computer. Along these lines, $74.58 \% \pm 4.90 \%$ of the students have a Smartphone, of which $80.3 \% \pm 6.90 \%$ from Pedagogy, $63.5 \% \pm 10.23 \%$ from Social Education and $77.2 \% \pm 8.57 \%$ from Pschopedagogy use it for personal use.

The analysis of Kruskal-Wallis test allows affirming that with few exceptions, the distribution of general variables frequencies from the questionnaire has no statistically significant differences among the diverse degrees. Exceptions include the age and access to the personal use of smartphones, which have already been detailed depending on the degree.

\subsection{Accomplishments in Learning Self-Regulation}

Data in Chart 1 shows the achievements in the three learning self-regulation stages in PLE. Most students defined their learning objectives in the forethought stage. Subsequently, in the performance stage, they were able to carry out their tasks in an organized manner, performing their extra work and handing them in within a reasonable timeframe. Finally, along the self-reflection stage, they got to reflect on the acquired knowledge.

Looking at the performance stage, we can notice some accomplishments in self-regulation in PLE, which are directly associated with information technologies: the population makes profitable use of technological tools from universities' web sites, and successfully use non-university technological tools. It is worth mentioning that the accomplishment of profitably using information was provided from external people.

On the other hand, we can see in Chart 1 that there are important proportions of students who cannot schedule their time successfully (30.1\%); neither can they read the whole material suggested by the teacher $(29.1 \%)$. This shows weak points in forethought and performance stages respectively.

Although most students from the population were able to enhance their knowledge in the subject units in the self-reflection stage, a significant percentage of students could not do so (29.76\%). Similarly in the same stage, a high percentage of students do not perform complementary researches of the subject units (48.83\%).

\subsection{Degrees Comparison}

Chart 1 shows that there are only four achievements in learning self-regulation in PLE: one in the forethought stage and three in the performance stage. These accomplishments present statistically significant differences among degrees.

In the forethought stage, getting adequate time allocation in order to perform the tasks have statistically significant differences among degrees ( $p=.006, H=10.20, E S=.1306$ ). As shown in Figure 1, Pyschopedagogy has the highest relative amount of students who strongly agree and agree with the factor the subject achieved adequate time allocation to perform their tasks. This means that Psychopedagogy students achieve this accomplishment in larger numbers and with more intensity than the other two degrees, followed by Pedagogy. This accomplishment has its lowest levels, both in number and intensity, in Social Education. In this degree, $42.35 \%$ of the students disagree or strongly disagree with achieving the accomplishment. 
Chart 1. Accomplishments in learning self-regulation in PLE, with total population.

\begin{tabular}{|c|c|c|c|c|c|}
\hline \multirow[b]{2}{*}{ Factors } & \multicolumn{4}{|c|}{ Relative frequencies with confidence intervals ${ }^{(1)}$} & \multirow{2}{*}{$\begin{array}{c}\% \\
\mathrm{NA}^{(2)}\end{array}$} \\
\hline & Strongly disagree & Disagree & Agree & Strongly agree & \\
\hline
\end{tabular}

Forethought stage

The subject defined their personal learning goals.

$\begin{array}{ccccc}0.33 & 10.37 & 76.59 & 12.37 & \\ {[.0, .99]} & {[6.92,13.82]} & {[71.82,81.35]} & {[8.65,16.10]} & .33 \\ 2.34 & & & & \\ {[.64,4.05]} & {[22.72,32.80]} & {[48.93,60.10]} & {[10.43,18.34]} & 1.00\end{array}$

The subject achieved adequate time allocation to perform their tasks. ${ }^{(3)}$

$[.64,4.05]$

$[22.72,32.80] \quad[48.93,60.10] \quad[10.43,18.34]$

.00

\section{Performance stage}

The subject met all the deadlines to hand in the classwork. ${ }^{(3)}$

$\begin{array}{lrrr}0.33 & 3.01 & 27.76 & 68.23\end{array}$

$[.0, .99] \quad[1.08,4.94] \quad[22.71,32.81] \quad[63.01,73.45]$

.67

The subject used non-university technological tools successfully. ${ }^{(3)}$

1.34

$[.04,2.64]$

4.01

$[1.80,6.23]$

39.13

54.85

$[33.63,44.63] \quad[49.25,60.45]$

.67

0.33

11.37

40.13

47.49

$[.0, .99]$

$[7.79,14.96]$

$[34.61,45.66]$

$[41.87,53.12]$

0.33

$[.0, .99]$

11.71

The subject carried out their tasks in an organized manner.

The subject profitably used technological tools from any university web site.

\subsection{3}

$[8.08,15.33]$

$$
56.86
$$

30.10

$[51.31,62.40] \quad[24.94,35.26]$

14.38

62.88

$[10.41,18.35]$

$[57.42,68.33]$

22.07

$[.0, .99]$

18.73 external people.

[1.08, 4.94]

[14.33, 23.13]

55.52

$[17.38,26.76]$

26.42

$[49.93,61.11]$

22.07

\subsection{8}

$[.85,4.50]$

[21.44, 31.41]

52.84

$[17.39,26.75]$

17.73

$[47.20,58.48] \quad[13.41,22.05]$

.67

1.00

.33

.67

.33

\section{Self-reflection stage}

The subject reflected on the acquired learning.

0.33

$[.0, .99]$

17.73

$[13.41,22.04]$

62.88

18.39

2.34

27.42

$[57.45,68.30]$

$[14.02,22.77]$

.67

$[.63,4.05]$

$[22.39,32.46]$

58.19

11.37 with.

5.69

43.14

$[52.65,63.74]$

[7.79, 14.96]

.67

$[3.07,8.31] \quad[37.55,48.74] \quad[38.21,49.42] \quad[4.13,9.91]$

The subject carried out complementary research of the units dealt with.

$\mathrm{N}=1062,{ }^{(1)} 95 \% \mathrm{CI},{ }^{(2)} \mathrm{NA}=$ No answer, ${ }^{(3)}$ Variables with statistically significant differences among degrees, Kruskal-Wallis test $\mathrm{H}>5.99, p<.05$, two tailed.

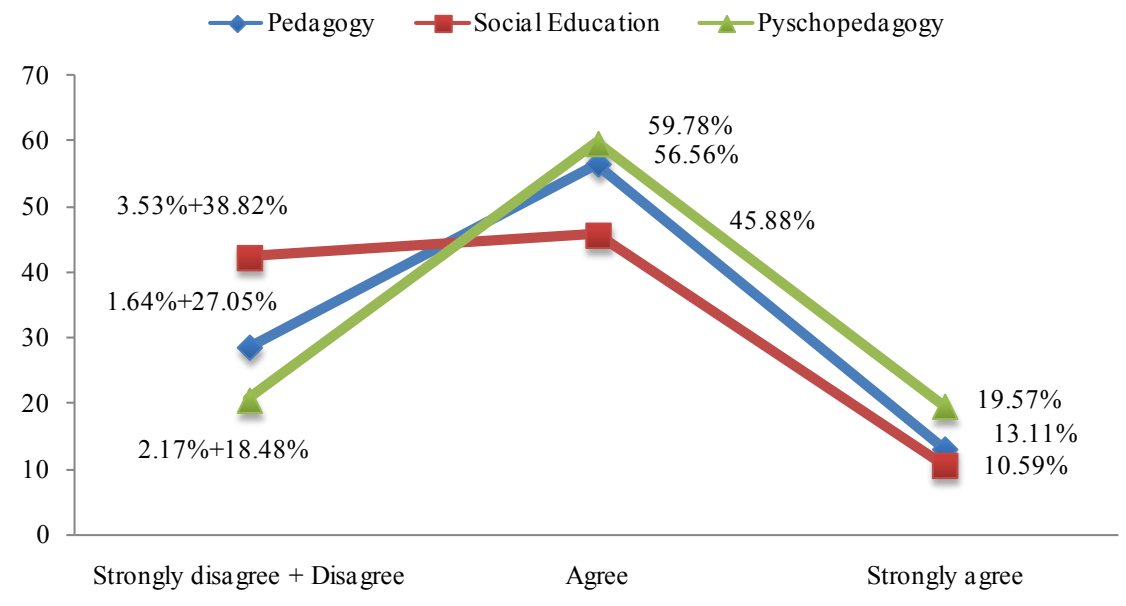

Figure 1. Relative frequencies of the variable "the subject achieved adequate time allocation to perform their tasks", depending on the degree. 
While Pedagogy and Psychopedagogy had very high percentages of students who strongly agree to the accomplishment. The subject met all the deadlines to hand in the classwork $(72.13 \% \pm 7.72 \%$ and $75 \% \pm 8.85 \%$ respectively), Social Education only got $55.29 \% \pm 10.57 \%$ in this option. For the same accomplishment, the option agree was chosen by $24.59 \% \pm 7.56 \%$ of the students in Pedagogy, $21.74 \% \pm 8.43 \%$ in Psychopedagogy and $38.82 \% \pm 10.36 \%$ in Social Education. This indicates most students in these three degrees achieved the accomplishment. However, statistically significant variations $(p=.006, H=10.25, E S=.1309)$ can be observed in the intensity of such accomplishment (Figure 2).

When using non-university technological tools, students from Pedagogy showed a higher perception of the accomplishment. This variable is statistically significant $(p=.038, H=6.53, E S=.1045)$. In this degree $63.11 \%$ $\pm 8.47 \%$ of the students strongly agree with having achieved the accomplishment, and $32.79 \% \pm 8.28 \%$ simply agree. On the other hand, in Social Education and Psychopedagogy, only $48.24 \% \pm 10.62 \%$ and $50 \% \pm 10.11 \%$ of the students respectively strongly agree with achieving the accomplishment. Similarly to the previous option, those who agree represent $42.35 \% \pm 10.50 \%$ in Social Education and $44.57 \% \pm 10.06 \%$ in Psychopedagogy (Figure 3).

Figure 4 shows Psychopedagogy has the highest percentage of students who read the whole material suggested by the teacher. Moreover, this degree shows the highest relative amount of students selecting the option strongly agree. This indicates that students from Psychopedagogy achieved this accomplishment in higher numbers and with more intensity than students from the other two degrees and, again, this is a statistically sig-

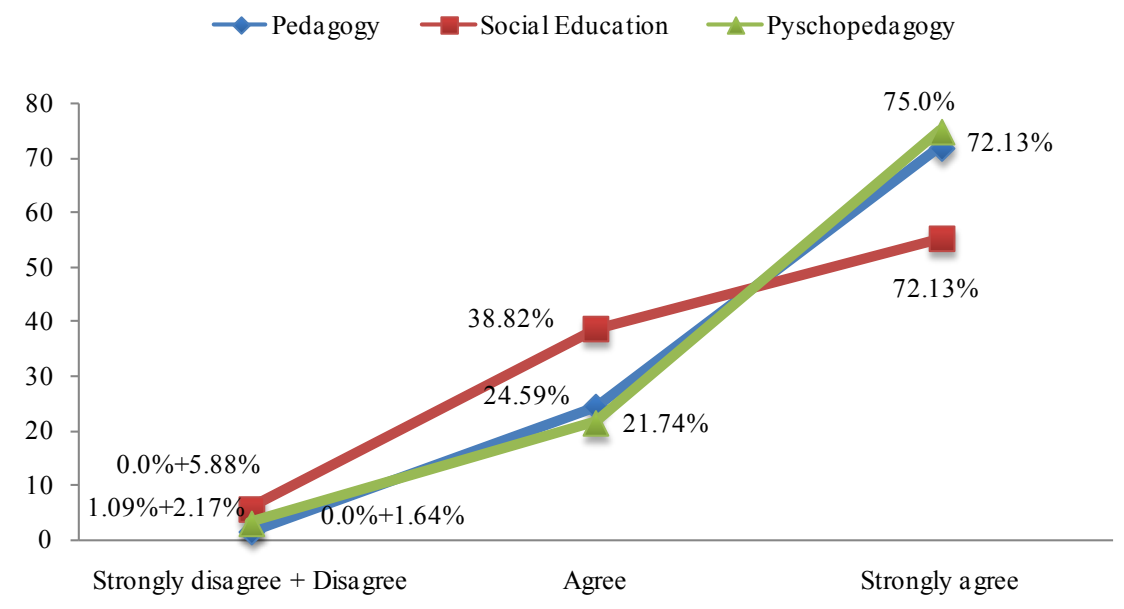

Figure 2. Relative frequencies of the variable "the subject met all the deadlines to hand in the classwork", depending on the degree.

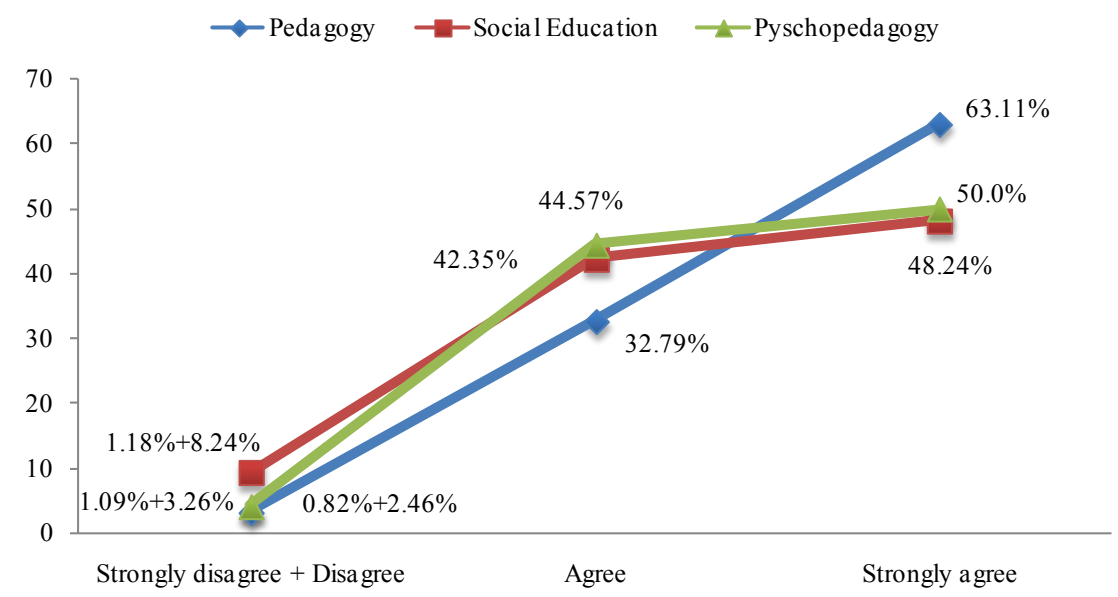

Figure 3. Relative frequencies of the variable "the subject used non-university technological tools successfully", depending on the degree. 


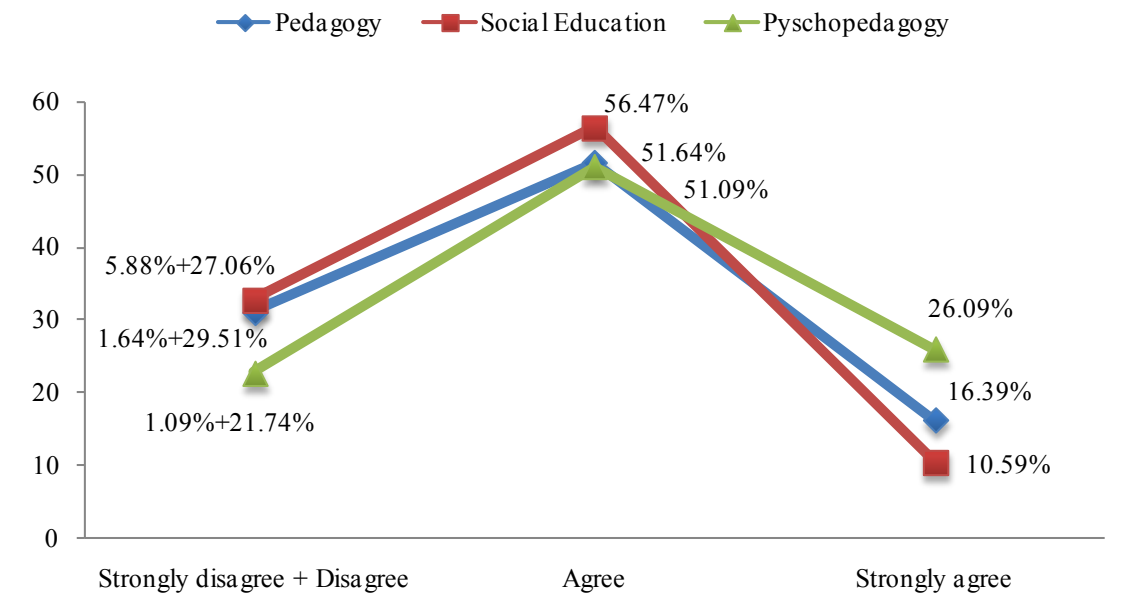

Figure 4. Relative frequencies of the variable "the subject could read the whole material suggested by the teacher", depending on the degree.

nificant difference $(p=.029, H=7.68, E S=.1113)$.

On the other hand, Pedagogy and Social Education show similar percentages of students who could read the whole material suggested by the teacher. Nonetheless, variation can be noted in this variable intensity, since Pedagogy has more students who strongly agree than Social Education. This means that the accomplishment is more firmly achieved in the first degree.

\subsection{Correlations among Accomplishments in Learning Self-Regulation}

Chart 2 correlation matrix presents two collections of four accomplishments each. Although there are correlations between the variables within each collection, there is no significant correlation with the variables of other collection. Such correlation could be a subject matter for future research.

In the first collection of accomplishments, it can be observed there is one significantly correlated with the other three, while these are independent. Students who could enhance their knowledge on the units dealt with could also read the whole material suggested by the teacher, research the units complementarily and reflect on the acquired knowledge. Inversely, students who achieved some of the last three accomplishments also enhanced their knowledge on the units dealt with.

Then, in the second collection, all of the accomplishments are correlated. This shows that, as a general rule, if a student succeeds in one of these accomplishments, he will achieve the four accomplishments at the same time. It can be inferred from this situation that there is a student subgroup that not only achieved adequate time allocation in the forethought stage, but also performed the extra work on time, carried out their tasks in an organized manner and met all the deadlines to hand in their class work in the performance stage.

The correlations also presented differences when the qualifications were compared. The correlation between the variable The subject could read the whole material suggested by the teacher (performance stage) and the variable The subject enhanced their knowledge on the units dealt with (self-reflection stage) presents differences among degrees. While Pedagogy shows a lightly significant correlation of 95\% IC [.09, .33], Social Education and Psychopedagogy present higher correlations: 95\% IC [.29, .53] and 95\% IC $[.20, .44]$ respectively.

It can be observed in Chart 3 that Pedagogy has the highest correlation between the variable "the subject achieved adequate time allocation to perform their tasks" (forethought stage) and the variable "the subject performed the extra work suggested by the teacher on time" (performance stage). Chart 3 also shows that Social Education has three correlation indexes higher than the other two degrees. According to the students of Social Education, meeting the deadlines to hand in the classwork is highly related to performing the extra work on time and carrying out the task in an organized manner. This accomplishment is closely linked during the performance stage to achieving adequate time allocation in the forethought stage.

\section{Analysis of Results}

Statistical tests show the three degrees share a homogeneous behavior in the majority of variables. Only six va- 
Chart 2. Relations among accomplishments in learning self-regulation in PLE.

\begin{tabular}{|c|c|c|c|c|c|}
\hline & \multirow{2}{*}{ Accomplishments } & \multicolumn{4}{|c|}{$\begin{array}{l}\text { Kendall's correlation coefficients }{ }^{(1)} \text { with } \\
\text { confidence intervals }^{(2)}\end{array}$} \\
\hline & & 1 & 2 & 3 & 4 \\
\hline 1 & The subject achieved adequate time allocation to perform their tasks & & & & \\
\hline 2 & $\begin{array}{l}\text { The subject performed the extra work suggested by the teacher } \\
\text { on time }\end{array}$ & {$[.39$} & & & \\
\hline 3 & The subject carried out their tasks in an organized manner & $\begin{array}{c}.55 \\
{[.47, .62]}\end{array}$ & $\begin{array}{c}.46 \\
{[.38, .54]}\end{array}$ & & \\
\hline 4 & The subject enhanced their knowledge on the units dealt with & - & - & - & \\
\hline 5 & The subject met all the deadlines to hand in the classwork & $\begin{array}{c}.34 \\
{[.26, .41]}\end{array}$ & $\begin{array}{c}.49 \\
{[.41, .57]}\end{array}$ & {$[. .35$} & - \\
\hline 6 & The subject could read the whole material suggested by the teacher & {$[.11, .27]$} & $\begin{array}{c}.19 \\
{[.11, .27]}\end{array}$ & - & {$\left[\begin{array}{c}.30 \\
{[.23, .38]}\end{array}\right.$} \\
\hline 7 & The subject carried out complementary research of the units dealt with & - & - & - & $\begin{array}{c}.38 \\
{[.31, .46]}\end{array}$ \\
\hline 8 & The subject reflected on the acquired learning & - & - & - & $\begin{array}{c}.30 \\
{[.22, .37]}\end{array}$ \\
\hline
\end{tabular}

$\mathrm{N}=1062,{ }^{(1)} p<.01$, two tailed tests and ${ }^{(2)} 95 \%$ IC.

Chart 3. Correlations among the accomplishments in learning self-regulation in PLE depending on the degree.

\begin{tabular}{|c|c|c|c|c|}
\hline & \multicolumn{3}{|c|}{ Kendall's correlation coefficients with $95 \%$ IC } & \\
\hline & Pedagogy & Social Education & Psychopedagogy & \\
\hline \multirow{3}{*}{$\begin{array}{l}\text { The subject achieved adequate } \\
\text { time allocation to perform their } \\
\text { tasks }\end{array}$} & $\stackrel{.42}{[.30, .54]}$ & $\begin{array}{c}.38 \\
{[.23, .52]}\end{array}$ & $\begin{array}{c}.33 \\
{[.19, .47]}\end{array}$ & $\begin{array}{l}\text { The subject performed the extra work } \\
\text { suggested by the teacher on time }\end{array}$ \\
\hline & $\begin{array}{c}.49 \\
{[.37, .61]}\end{array}$ & $\stackrel{.61}{[.46, .75]}$ & $\begin{array}{c}.54 \\
{[.41, .68]}\end{array}$ & $\begin{array}{l}\text { The subject carried out their tasks in } \\
\text { an organized manner }\end{array}$ \\
\hline & {$[.20, .44]$} & $\begin{array}{c}.30 \\
{[.16, .45]}\end{array}$ & $\begin{array}{c}.32 \\
{[.18, .46]}\end{array}$ & \\
\hline $\begin{array}{l}\text { The subject performed the extra } \\
\text { work suggested by the teacher on } \\
\text { time }\end{array}$ & $\begin{array}{c}.46 \\
{[.34, .58]}\end{array}$ & $\begin{array}{l}.57 \\
{[.42, .71]}\end{array}$ & $\begin{array}{c}.43 \\
{[.29, .57]}\end{array}$ & $\begin{array}{l}\text { The subject met all the deadlines to } \\
\text { hand in the classwork }\end{array}$ \\
\hline $\begin{array}{l}\text { The subject carried out their tasks } \\
\text { in an organized manner }\end{array}$ & $\begin{array}{c}.32 \\
{[.20, .44]}\end{array}$ & $\stackrel{.41}{[.26, .55]}$ & $\begin{array}{c}.28 \\
{[.14, .42]}\end{array}$ & \\
\hline
\end{tabular}

$p<.01$, two tailed tests.

riables out of twenty-one present statistically significant differences among degrees. Two of them are general and four are main variables and the effect size is not very high in these cases. On average, the students from Pedagogy are two years younger than the students from the other two degrees and have the highest personal access to smartphone: an important $17 \%$ more than Social Education.

The population is in general successful in the three stages of learning self-regulation in PLE. This is very positive as the social cognitive perspective states that when successful in a concrete task, the subject builds confidence in their own capacity to perform related or similar tasks, and this is a source of motivation for new actions (Pintrich \& Schunk, 2002).

However, the students present some weak points along the stages. It is necessary to reinforce the time planning in order to properly allocate it for performing the tasks in forethought stage and boost the reading of materials provided by the teacher in performance stages. During self-reflection stage, there is a need to reinforce the enhancement of knowledge and complementary research of the subject units. Additionally, it would be interesting to perform deeper research in order to establish aspects and reasons why students from this population do not achieve these accomplishments. In this research and reinforcement process, teachers play an important role, since in formal education environments they must provide effective orientation and consistent feedback towards 
the development of abilities and knowledge for learning self-regulation. The reinforcement of weak aspects will allow increasing the perception of self-efficacy in students, which will boost their motivation (Zimmerman \& Cleary, 2006, 2009). Also, student uncertainty will be reduced through their own self-control. This means the students will increase their control over their capacity to prevent failure and will see a higher connection between their effort and success (Covington, 1992; McInerney, 2000; Martin, 2007, 2008, 2009).

Of the twelve variables dealing with the accomplishments in learning self-regulation, only four variables present statistically significant differences among degrees. In Psychopedagogy, the students who strongly agree with achieving adequate time allocation to perform their tasks represent $6 \%$ more and $9 \%$ more than in Pedagogy and Social Education, respectively. A larger number of students from this population think they meet the deadlines to hand in the classwork. This is to say there is a relatively large amount of students choosing the options agree and strongly agree. Nevertheless, the percentage of students from Social Education who strongly agree is approximately 18 and 20 percentage points lower than Pedagogy and Pyschopedagogy, respectively. This means Social Education students perceive the accomplishment less intensely than the rest.

The students from the three degrees agree with using non-university tools successfully. However, the number of students in Pedagogy who strongly agree, and therefore achieve this accomplishment more intensely, is $15 \%$ and $13 \%$ higher than in Social Education and Psychopedagogy, respectively.

The students from Psychopedagogy achieved the reading of the material suggested by the teacher in greater proportion and more intensively. From all its students, $77.18 \%$ think they achieved the accomplishment and from that percentage, $26.09 \%$ perceived it more intensively. This is followed by the students of Pedagogy, with lower numbers and intensity. Finally, we find Social Education students, where $67.03 \%$ think they achieved the accomplishment and $10.59 \%$ chose the option strongly agree.

Additionally, the students from Psychopedagogy excel in achieving adequate time allocation to perform their tasks. This way, $79.35 \%$ achieve this accomplishment and $19.57 \%$ strongly agree with achieving it. Again, the students from Social Education are beneath the other degrees in both number of students and in intensity.

It can be inferred from the correlation analysis that the group of students enhancing their knowledge in the units dealt with also achieved the reading of the whole material suggested by the teacher, the complementary research of the units dealt with, and the reflection on their learning. The correlation between enhancing the knowledge and the reading of the whole material is especially clear in Social Education and Psychopedagogy. These results are important for the training programs managers and for the researchers, as any teaching action promoting the reading of the material suggested by the teacher will most probably enforce the other accomplishments. The theory indicates that increasing the student's success will also increase the positive perception of their self-efficacy. This will at the same time influence the student to self-regulate their learning in a persistent, active and motivated manner (Zimmerman, 2006; Bandura, 2006).

There is another student subgroup which achieved four accomplishments in their learning self-regulation in PLE. This subgroup achieved adequate time allocation in the forethought stage and performed the extra work on time, worked in an organized way and met the deadlines to hand in the classwork in the performance stage. This result is consistent with the theory, which indicates the interconnection among the different stages of the learning self-regulation process (Zimmerman \& Schunk, 1989; Schunk \& Zimmerman, 1994; Zimmerman, 2000; Schunk \& Zimmerman, 2003). It would be advisable to research this student group in depth in order to properly boost the planning of time in the first stage of learning self-regulation and achieve higher accomplishments during the performance stage.

A possible limitation of the research might be it measures the students' perception over their accomplishments. Therefore, there are external factors which could affect these perceptions. For instance, higher levels of sellcriticism could lead to lower levels of the accomplishment perception.

\section{Conclusion}

With this research, we come to the following conclusions associated with the learning self-regulation in PLE:

1) The population does not present great differences among degrees with regard to the accomplishments in learning self-regulation in PLE.

2) The population achieves accomplishments in learning self-regulation in PLE. Nonetheless, there is a need to reinforce the time planning, the reading of the material suggested by the teacher, the enhancement of knowledge and the complementary research. 
3) There are student subgroups which excel thanks to certain accomplishments. One of these stands out in the organization and performance of tasks. The other subgroup excels by its enhancement of knowledge and metacognition. A deeper knowledge of these two student subgroups can help achieve greater success in the learning self-regulation in PLE.

4) In concurrence with the theory, relations among the accomplishments of the different stages of learning self-regulation have been identified. If the accomplishments in one stage are reinforced, then the accomplishments in the other stages will also be reinforced.

\section{References}

Archee, R. (2012). Reflections on Personal Learning Environments: Theory and Practice. Procedia-Social and Behavioral Sciences, 55, 419-428. http://dx.doi.org/10.1016/j.sbspro.2012.09.520

Aron, A., Coups, E. J., \& Aron, E. N. (2013). Statistics Psychology (6th ed.). Upper Sadle River, NJ: Pearson Education, Inc.

Attwell, G. (2007a). E-portfolios-The DNA of the Personal Learning Environment? Journal of e-Learning and Knowledge Society, 3, 39-61.

Attwell, G. (2007b). Personal Learning Environments-The Future of eLearning? Elearning Papers, 2, 1-7.

Bandura, A. (1997). Self-Efficacy: The Exercise of Control. New York: Freeman.

Bandura, A. (2006). Guide for Constructing Self-Efficacy Scales. In F. Pajares, \& T. Urdan (Eds.), Self-Efficacy Beliefs of Adolescents (Vol. 5, pp. 307-337). Greenwich, CT: Information Age Publishing.

Broadbent, J., \& Poon, W. L. (2015). Self-Regulated Learning Strategies \& Academic Achievement in Online Higher Education Learning Environments: A Systematic Review. The Internet and Higher Education,27, 1-13. http://dx.doi.org/10.1016/i.iheduc.2015.04.007

Carver, C. S., \& Scheier, M. F. (1998). On the Self-Regulation of Behavior. New York, NY: Cambridge University Press.

Chatti, M. A., Agustiawan, M. R., Jarke, M., \& Specht, M. (2010). Toward a Personal Learning Environment Framework. International Journal of Virtual and Personal Learning Environments, 1, 66-85.

Chaves, E. (2014). Investigación educativa sobre autogestión en los Entornos Personales de Aprendizaje (PLE): Una revisión de la literatura. EDMETIC, Revista de Educación Mediática y TIC, 3, 114-134.

Chaves, E., Trujillo, J. M., \& López, J. A. (2015). Autorregulación del aprendizaje en entornos personales de aprendizaje en el Grado de Educación Primaria de la Universidad de Granada, España. Formación Universitaria, 8, en prensa.

Covington, M. V. (1992). Making the Grade: A Self-Worth Perspective on Motivation and School Reform. Cambridge: Cambridge University Press. http://dx.doi.org/10.1017/CBO9781139173582

Cronbach, L. J. (1951). Coefficient Alpha and the Internal Structure of Test. Psychometrika, 16, $297-334$. http://dx.doi.org/10.1007/BF02310555

Dabbagh, N., \& Kitsantas, A. (2012). Personal Learning Environments, Social Media, and Self-Regulated Learning: A Natural Formula for Connecting Formal and Informal Learning. The Internet and Higher Education, 15, 3-8. http://dx.doi.org/10.1016/j.iheduc.2011.06.002

Drexler, W. (2010). The Networked Student Model for Construction of Personal Learning Environments: Balancing Teacher Control and Student Autonomy. Australasian Journal of Educational Technology, 26, 369-385.

Ebner, M., \& Taraghi, B. (2010). Personal Learning Environment for Higher Education-A First Prototype. Proceedings of the World Conference on Educational Multimedia, Hypermedia and Telecommunications, Toronto, 28 June-2 July 2010 , 1158-1166.

Forgas J. P., Baumeister R. F., \& Tice D. M. (2009). Psychology and Self-Regulation: Cognitive, Affective, and Motivational Processes. New York: Psychology Press.

Gillet, D., Law, E., \& Chatterjee, A. (2010). Personal Learning Environments in a Global Higher Engineering Education Web 2.0 Realm. Proceedings of the IEEE Global Engineering Education Conference, Madrid, 14-16 April 2010, 897-906. http://dx.doi.org/10.1109/educon.2010.5492483

Godwin-Jones, R. (2009). Emerging Technologies: Personal Learning Environments. Language Learning \& Technology, 13, 3-9.

Hadwin, A. F., Oshige, M., Gress, C. L. Z., \& Winne, P. H. (2010). Innovative Ways for Using Study to Orchestrate and Research Social Aspects of Self-Regulated Learning. Computers in Human Behavior, 26, 794-805. http://dx.doi.org/10.1016/j.chb.2007.06.007

Haslaman, T., \& Askar, P. (2015). The Measures of Students' Self-Regulated Learning and Teachers' Supportive Self-Regulated Learning Behaviors. Hacettepe University Journal of Education, 30, 106-121. 
Howell, D. C. (2014). Fundamental Statistics for the Behavioral Sciences (8th ed.). Belmont, CA: Wadsworth.

Jin, P., \& Low, R. (2009). Enhancing Motivation and Self-Regulated Learning in Multimedia Environments. In R. D. Koo, B. C. Choi, M. R. D. Lucas, \& T. C. Chan (Eds.), Education Policy, Reform, and School Innovations in the Asia-Pacific Region (pp. 525-547). Hong Kong: Association for Childhood Education International-Hong Kong \& Macao (ACEI-HKM).

Johnson, M. W., \& Liber, O. (2008). The Personal Learning Environment and the Human Condition: From Theory to Teaching Practice. Interactive Learning Environments, 16, 3-15. http://dx.doi.org/10.1080/10494820701772652

Johnson, M. W., \& Sherlock, D. (2014). Beyond the Personal Learning Environment: Attachment and Control in the Classroom of the Future. Interactive Learning Environments, 22, 146-164. http://dx.doi.org/10.1080/10494820.2012.745434

Kendall, M. G., \& Stuart. A. (1979). The Advanced Theory of Statistics (4th ed.). New York: Hafner Press.

Kruskal, W. H., \& Wallis, W. A. (1952). Use of Ranks in One-Criterion Variance Analysis. Journal of the American Statistical Association, 47, 583-621. http://dx.doi.org/10.1080/01621459.1952.10483441

Leech, N., Barrett, K., \& Morgan, G. (2011). IBM SPSS for Intermediate Statistics, Use and Interpretation. New York: Taylor and Francis Group, LLC.

Liber, O., \& Johnson, M. (2008). Personal Learning Environments. Interactive Learning Environments, 16, 1-2. http://dx.doi.org/10.1080/10494820701772645

Martin, A. J. (2007). Examining a Multidimensional Model of Student Motivation and Engagement Using a Construct Validation Approach. British Journal of Educational Psychology, 77, 413-440. http://dx.doi.org/10.1348/000709906X118036

Martin, A. J. (2008). Enhancing Student Motivation and Engagement: The Effects of a Multidimensional Intervention. Contemporary Educational Psychology, 33, 239-269. http://dx.doi.org/10.1016/j.cedpsych.2006.11.003

Martin, A. J. (2009). The Motivation and Engagement Scale-User Manual (9th ed.). Sydney: Lifelong Achievement Group. www.lifelongachievement.com

McInerney, D. (2000). Helping Kids Achieve Their Best. Sydney: Allen and Unwin.

Nelson, K. G., Shell, D. F., Husman, J., Fishman, E. J., \& Soh, L. K. (2015). Motivational and Self-Regulated Learning Profiles of Students Taking a Foundational Engineering Course. Journal of Engineering Education, 104, 74-100. http://dx.doi.org/10.1002/jee.20066

Osterlind, S.J. (1989). Constructing Tests Items. Boston, MA: Kluwer Academic Publishers. http://dx.doi.org/10.1007/978-94-009-1071-3

Pajares, F. (2002). Gender and Perceived Self-Efficacy in Self-Regulated Learning. Theory into Practice, 41, 116-225. http://dx.doi.org/10.1207/s15430421tip4102_8

Pajares, F. (2007). Motivational Role of Self-Efficacy Beliefs in Self-Regulated Learning. In B. J. Zimmerman, \& D. H. Schunk (Eds.), Motivation and Self-Regulated Learning: Theory, Research, and Applications (pp. 111-140). New York: Erlbaum.

Pintrich, P., \& Schunk, D. (2002). Motivation in Education: Theory, Research, and Application (2nd ed.). Upper Saddle River, NJ: Merrill Prentice Hall.

Rahimi, E., \& Jan Van den Berg, W. V. (2015). Facilitating Student-Driven Constructing of Learning Environments Using Web 2.0 Personal Learning Environments. Computers \& Education, 81, 235-246. http://dx.doi.org/10.1016/j.compedu.2014.10.012

Rezaee, R., \& Mosalanejad, L. (2015). The Effects of Case-Based Team Learning on Students' Learning, Self Regulation and Self Direction. Global Journal of Health Science, 7, 295-306. http://dx.doi.org/10.5539/gjhs.v7n4p295

Ricoy, C., \& Cuoto, M. J. (2010). El alumnado de secundaria y el ambiente Personal de aprendizaje en Internet. Proceedings of the PLE Conference. Barcelona, 8-9 July 2010, 131-143.

Schunk, D. H. (2004). Learning Theories: An Educational Perspective (4th ed.). Upper Saddle River, NJ: Pearson Education.

Schunk, D. H., \& Zimmerman, B. (2003). Self-Regulation and Learning. In W. M. Reynolds, \& G. E. Miller (Eds.), Handbook of Psychology (Vol. 7): Educational Psychology (pp. 59-78). Hoboken, NJ: Wiley.

http://dx.doi.org/10.1002/0471264385.wei0704

Schunk, D. H., \& Zimmerman, B. J. (Eds.) (1994). Self-Regulation of Learning and Performance. Hillsdale: Lawrence Er1baum.

Usher, E. L., \& Pajares, F. (2008). Self-Efficacy for Self-Regulated Learning: A Validation Study. Educational and Psychological Measurement, 68, 443-463. http://dx.doi.org/10.1177/0013164407308475

Väljataga, T., \& Laanpere, M. (2010). Learner Control and Personal Learning Environment: A Challenge for Instructional Design. Interactive Learning Environments, 18, 277-291. http://dx.doi.org/10.1080/10494820.2010.500546

Vanthournout, G., Kyndt, E., Gijbels, D., \& Van den Bossche, P. (2015). Understanding the Direct and Indirect Relations 
between Motivation to Participate, Goal Orientation and the Use of Self-Regulation Strategies during a Formal Training. Zeitschrift für Erziehungswissenschaft, 18, 89-106. http://dx.doi.org/10.1007/s11618-014-0601-7

Wilson, S. (2008). Patterns of Personal Learning Environments. Interactive Learning Environments, 16, 17-34. http://dx.doi.org/10.1080/10494820701772660

Wilson, S., Liber, O., Johnson, M., Beauvoir, P., Sharples, P., \& Milligan, C. (2007). Personal Learning Environments: Challenging the Dominant Design of Educational Systems. Journal of E-Learning and Knowledge Society, 2, 1-11.

Winne, P. H. (2015). Self-Regulated Learning. In J. D. Wright (Ed.), International Encyclopedia of the Social \& Behavioral Sciences (pp. 535-540). Oxford: Elsevier. http://dx.doi.org/10.1016/B978-0-08-097086-8.25091-5

Zimmerman, B. J. (1990). Self-Regulated Learning and Academic Achievement: An Overview. Educational Psychologist, 25, 3-17. http://dx.doi.org/10.1207/s15326985ep2501_2

Zimmerman, B. J. (2000). Attaining Self-Regulation: A Social Cognitive Perspective. In M. Boekaerts, P. R. Pintrich, \& M. Zeidner (Eds.), Handbook of Self-Regulation (pp. 13-39). San Diego, CA: Academic Press. http://dx.doi.org/10.1016/B978-012109890-2/50031-7

Zimmerman, B. J. (2006). Self-Regulation and Effective Learning. In: D. M. McInerney, \& V. McInerney (Eds.), Educational Psychology: Constructing Learning (pp. 190-191). Sydney: Pearson Education.

Zimmerman, B. J. (2008). Investigating Self-Regulation and Motivation: Historical Background, Methodological Development, and Future Prospects. American Educational Research Journal, 45, 166-183. http://dx.doi.org/10.3102/0002831207312909

Zimmerman, B. J. (2015). Self-Regulated Learning: Theories, Measures, and Outcomes. In J. D. Wright (Ed.), International Encyclopedia of the Social \& Behavioral Sciences (pp. 541-546). Oxford: Elsevier. http://dx.doi.org/10.1016/B978-0-08-097086-8.26060-1

Zimmerman, B. J., \& Cleary, T. J. (2006). Adolescents' Development of Personal Agency. In F. Pajares, \& T. Urdan (Eds.), Adolescence and Education (Vol. 5): Self-Efficacy Beliefs of Adolescents (pp. 45-69). Greenwich, CT: Information Age Publishing.

Zimmerman, B. J., \& Cleary, T. J. (2009). Motives to Self-Regulate Learning. In K. R. Wentzel, \& A. Wigfield (Eds.), Handbook of Motivation at School (pp. 247-264). New York: Routledge.

Zimmerman, B. J., \& Schunk, D. H. (Eds.) (1989). Self-Regulated Learning and Academic Achievement: Theory, Research and Practice. New York: Springer. http://dx.doi.org/10.1007/978-1-4612-3618-4 